\title{
Deciphering FARC was to Disarm it. Razón Pública's Framing of FARC
}

Recibido: 29/07/2020 | Revisado: 18/02/2021 | Aceptado: 20/02/2021

DOI: 10.17230/co-herencia.18.34.7

\section{Emilio Calderón-Reyes*}

emiliocalderonr@gmail.com

\begin{abstract}
This article analyzes the framing of the Revolutionary Armed Forces (FARC-EP) in Razón Pública, a Colombian digital magazine, from July 2008 to July 2018. The article's methodology combines Natural Language Processing and close reading. Results indicate that the magazine's language primarily framed FARC as a protagonist of the peace process, and, secondarily, as an actor of Colombia's armed conflict and drug trafficking. Shortly after Juan Manuel Santos' first inauguration as Colombian president (2010-2014), some authors forecasted that the conditions were ripe for a peace process with FARC. During the official negotiation, FARC was framed as enigmatic, and rational protagonist of a challenging peace process. Overall, the frames detected in this analysis are an echo of the UNDP Colombian Report (2003) that called for analytic journalism that improves the public's understanding of the country's complex armed conflict and proposes negotiated and military solutions.
\end{abstract}

\section{Keywords:}

FARC, peace, conflict, topic modeling, framing, negotiation.

\section{Descifrar a las FARC era desarmarlas. EI framing usado por la revista Razón Pública para las FARC}

Resumen Este artículo analiza cómo se enmarcó a las FARC en la revista Razón Pública entre julio de 2008 y julio de 2018, utilizando una combinación de procesamiento de lenguaje natural y lectura atenta. En el análisis del lenguaje se halló que la revista enmarcó principalmente a las FARC como protagonistas del proceso de paz y, en segundo lugar, como actores del conflicto armado y del tráfico de drogas. Al poco tiempo de la primera toma de posesión de Juan Manuel Santos, algunos autores pronosticaron que las circunstancias 
eran propicias para que se diera un proceso de paz con las FARC. Durante el tiempo que las negociaciones se llevaron a cabo oficialmente, se tendió a enmarcar a las FARC como una organización enigmática, sospechosa y, a la vez, racional. Este marco se centró en examinar el desarrollo, los desafíos e implicaciones del proceso de paz. En general, los marcos detectados hacen eco al llamado del reporte Colombia: Callejón con salida sobre la necesidad de un cubrimiento analítico que contribuya a la comprensión del público de la complejidad del conflicto armado, y proponga soluciones negociadas y militares.

\section{Palabras clave:}

FARC, paz, conflicto, modelización temática, framing, negociación.

Established in 1964, the Revolutionary Armed Forces (FARCEP) existed as an active Colombian Marxist guerrilla for over 53 years. In the twentieth century, the Colombian government and FARC-EP held multiple peace negotiations, none of which achieved the complete demobilization of the guerrilla or a definitive end to hostilities. The latest of these, during Andrés Pastrana government (1998-2002), was terminated by the president in response to FARC breaching the conditions of the negotiation by continuing its armed activities and seeking to grow its power. After this failed attempt, Pastrana and his successors, Álvaro Uribe Vélez (2002-2010) and Juan Manuel Santos (2010-2018) implemented counter-insurgence policies directed to defeating FARC military, through: Plan Colombia, Plan Patriota, and Espada de Honor.

In 2012, a new peace negotiation between the Colombian government and Revolutionary Armed Forces was officially announced. After four years of challenging negotiations, for the most part, concurrent to combats, fierce political opposition, and even a plebiscite in which a peace deal was rejected by a slight majority, the Colombian government and FARC signed a final peace deal. The Final Peace Agreements of Habana, 2016, lay down the terms for demobilization of FARC as a guerrilla organization, and its transformation into the Common Alternative Revolutionary Force (FARC) political party, as well as a series of political reforms.

Considering the historical significance of the Final Peace Agreement and FARC's disarming, it is worth examining how 
scholars contributed to public deliberation by communicating their insight on this matter as it happened. Since the popularization of blogs and the rise of social media by the mid 2000s, there has been an expansion of spaces available for people to produce and disseminate their own content. In the case of academics, this has meant new possibilities to communicate their knowledge and perspectives on current affairs other than research publications.

This study is centered in how FARC was framed in Razón Pública, a Colombian non-profit digital magazine. The magazine's objectives are: (i) to provide a reflective, contextualized and purposeful view of current affairs by experts, (ii) to become a convergence point for academic communities to reflect on current affairs, (iii) to make these analyses available to anyone interested, and to channel them to decision-makers (Razón Pública, 2009). These objectives make Razón Pública a relevant case for studying which were the frames from which this network of academics analyzed FARC's transformation from a being one of the oldest guerrilla group in the continent to become a political party.

The period studied, July 2008- July 2018, covers the magazine's first ten years. This period included the four years preceding the announcement of the peace negotiations between FARC and the Colombian government in September of 2012, the subsequent four years of Peace Negotiations in Habana until the official signing of the treaty in September of 2016, and the first twenty-two months of its implementation.

The dataset analyzed consisted of the 4609 articles published in Razón Pública in the magazine first ten years. I built this dataset using web scrapping, and, I analyzed its prevalent topics and language in my Master thesis. ${ }^{1}$ Using Natural Language Processing (NLP), I quantified how much coverage was given to FARC in these articles and interpreted how the language used framed this organization. Specifically, the three NLP methods used were: keywords network, $\mathrm{n}$-grams and LDA topic modeling. To deepen the analysis of the frames and their relations with the academic debate about Colombia's

Calderón Reyes (2019), Public Interest in Razón Pública: a Data-driven Network Analysis. 
civil war and peace, I conducted a close reading of the articles with the highest concentrations of these topics.

In Entman's (1993) media studies seminal definition of framing, framing is the action of selecting and giving salience to specific information recurrently. The media's framing of current affairs plays a major role in setting the political agenda, and also influences how problems are conceived and examined. This article follows Anttila, Eranti and Kukkonen (2018) approach of using LDA topic modeling to identify news frames, understood as recurrent relations between concepts in large corpora. In addition, the article's n-grams and keywords network identified in this analysis show the concepts and language most associated with FARC in Razón Pública. For example, topic modeling has been used to identify changes in newspapers' articles across time and to examine how the media addressed diverse social and cultural issues (DiMaggio et al., 2013; Newman \& Block, 2006). DiMaggio et al. (2013) say that some of the topics obtained with LDA may be regarded as frames if they present "[...] semantic contexts that prime particular associations or interpretations of a phenomenon in a reader" (p. 578). It is worth mentioning that the term "frames" is used in social sciences to refer to cognitive structures developed discursively that shape the way in which people make sense of the world.

While discourse analysis is the mainstream approach for deconstructing news framing (Brüggeman, 2014), an alternative approach is to apply the computational methods. The scalability of computational methods is its main advantage over traditional discourse analysis in which a constricted corpus is systematically annotated and analyzed by the researcher. The results obtained in this research show that, for the most part, FARC was framed as a protagonist of the peace negotiation, an that FARC also had a significant, yet secondarily, connection to drug trafficking and violence. After reading the articles and list of terms most representative of these topics, I interpreted that in the frame of peace making FARC was presented as a rational agent that, while unreliable and unpredictable, had multiple reasons to negotiate with the Colombian government. 


\section{Literature review}

\section{Characterizations of war in Colombia}

The long-lived discussion about how to characterize Colombia's war has been a central topic of collaborative research initiatives, most notably, the United Nations Development Program Conflicto Callejón sin salida (2003), Nuestra guerra sin nombre of the Instituto de Estudios Políticos y Relaciones Internacionales (2006), and Contribución al entendimiento del conflicto armado en Colombia by the Comisión Histórica del Conflicto y sus Víctimas (2015). In these publications, renowned researchers examined the complexity of the conflict from its historical origins up to the present, seeking to contribute to how Colombians conceive and transform their society. The fundamental commonality of these documents is the acknowledgement of the complexity of the Colombian armed conflict with its deep connections to politics, criminality, weak democratic institutions, and private interests.

To contextualize the academic debate about the characterization of war in Colombia, it is worth considering the country's public policy towards FARC. The Belisario Betancur administration (1982-1986) was the first government to acknowledge the political motivations of the multiple guerrillas, which until then had been considered purely criminal groups that threatened public order (UNDP, 2003). Most subsequent governments recognized FARC's political motivations: César Gaviria (1990-1994), Ernesto Samper (1994-1998), Andrés Pastrana (1998-2002), and Juan Manuel Santos (2010-2018). In contrast to these administrations, Alvaro Uribe's government (2002-2010) denied the existence of an armed conflict with FARC, recurrently characterizing it as a narco-terrorist organization (Pecáut, 2015, p. 655)

According to Gutiérrez Sanín and Sánchez Gómez (2006), while there is an overall consensus among researchers in that Colombia has been at war in the last decades, it is highly contended if it is best characterized as a civil war, a war against civil society, an apolitical war or a new type of war (p. 7). Gutiérrez Sanín and Sánchez Gómez stress the complexity of this ongoing war and caution against 
misconceiving it under false dichotomies: (i) the local/national and the global, (ii) crime and politics, (iii) economy and politics, (iv) democracy and violence, (v) disorder and law. These authors consider that any agreement regarding the conceptualization of war in Colombia passes through looking beyond these false dichotomies, as well as acknowledging the diverse and incongruous motivations of the actors involved at the multiple scales in which it took place.

The debate about whether the situation of Colombia is best described as a civil war or conflict continued in Contribución al entendimiento del conflicto armado colombiano. The publication's title follows the FARC-Government peace process in using the expression "armed conflict", yet some authors debated how to name it. Half of the essayists preferred the expression "armed social conflict" to highlight the relations between political violence and social conflict (Pizarro Leongómez, 2015, p. 60). Among the authors who employed alternative terms, Obregón named it an "old new war" (2015, p. 814) to call attention to the continuities and discontinuities of political violence in Colombia. Meanwhile, Francisco Gutiérrez considered it a "civil war" with two major waves, the partisan Violencia (late 40'searly 60'), and a counter-insurgency war continuing to the present (2015, p. 521). Daniel Pécaut opposed considering the latest decades of the conflict a civil war because civil society was brutalized even though most civilians did not side with any faction (2015, p. 640). Meanwhile, Jorge Giraldo's (2015, pp. 741-743) characterized the country's war as multipolar, fragmented, geographically dispersed, and atrocious for the high rate of civilian casualties. In his Relatoría, Pizarro Leongómez reiterated Giraldo's characterization, albeit he substituted the term war with armed conflict (pp. 58-61). Addressing the false dichotomy between politics and criminality, Pizarro Leongómez characterized the conflict as having political causes and effects because, even if some criminal actors lacked political intentions, their participation undermined the state and questioned its legitimacy.

To further clarify the significance of the various names given to Colombia's contemporary war, it is worth referencing Giraldo's (2009) diagram of Francis A. Beer's conceptualization of war. In the 
diagram's first level, the meaning of war consists of a nuclear concept, understood as the common-sense distinction between war and nowar, and a contextual component (p. 35). The context is formed, in the second level, by the combination of the cognitive, behavioral and textual dimensions that shape how war has been understood across cultures and epochs. In turn, at the third level, the textual dimension covers all the various names, terminology and narratives used to talk about war. Following Beer's scheme, there exists a general consensus in that Colombia has been at war in the last fifty years in the nuclear meaning of the term, and researchers and politicians contend regarding which terminology better describes it -such as armed conflict, civil war, terrorism, or criminal uprising-, and its legal and political implications.

Since the end of the Second World War, some researchers have proposed multiple terms in replacement of civil wars that tend to highlight a distinct facet of a set of empirical cases, such as the military techniques employed or its causes (Giraldo, 2009, pp. 4546). Jorge Giraldo criticized substituting names of civil war because doing so contributes to obscuring the debate, being prone to biases, subjective evaluations and theoretically shallow. Giraldo considered that the definition of internal armed conflict of the Additional Protocols of the Geneva Conventions (1979) was a normative attempt to forbid war, and, in reality, has only serve to obscure the existence of contemporary civil wars (p. 55). Based on this analysis, it could be said that the Final Peace Agreement of Habana veiled the Colombian civil war by consistently referring to it as an internal armed conflict.

\section{The Colombian media and war}

Chapter 18 of the 2003 United Nations Development Program Report (UNDP) for Colombia examined the coverage of the conflict by the national media and how it shaped the public's perception about it. The report assessed the media's coverage of the conflict as being short-sighted, prone to erroneous simplifications and reactive, for its focus on reporting the most recent violent episodes 
without sufficient context. The report states that the best way in which the media can contribute to the public's understanding of the conflict is to offer more analyses, peace practices, and discussions about solutions to the conflict and commitment building (pp. 430431). The UNDP report proposes that a more analytical, in-depth, contextualized, prospective and public-interest-oriented journalism could potentially transform Colombian social imaginaries to become more conducive to ending the country's vicious circle of violence.

Razón Pública's mission statement (2009) echoed the Chapter 14 of the UNDP report, as both shared the vision that analytical, contextualized, and public-interest-oriented journalism could contribute to political solutions to the country's main challenges. Moreover, some of the contributors to the report later co-founded Razón Pública, among them Maria Victoria Duque -manager of the report and co-founder of the magazine- and Hernando Gómez Buendía -director of both publications.

In a more recent account of the relationships between conflict and journalism, the International Center for Transitional Justice (2016) considered that the media influences public opinion either to support or oppose transitional justice and peace negotiation processes. In these scenarios, the organization prescribed that the media's coverage of armed conflicts should appeal to empathy and reconciliation, strive to humanize victims, and avoid fueling fear and hatred. Similar conclusions were reached by The Gabo Foundation for New Journalism (2019) based on reviewing one hundred projects, which they presented as examples of journalism that fostered reconciliation and peace in Colombia.

\section{Politics and journalism in the coverage of the Habana's peace negotiation}

The large inventory of projects presented in the Gabo Foundation for New Journalism evidenced a boom of peace journalism projects during the peace negotiation. For Barajas (2016), promoting peace journalism was a tacit strategy of Juan Manuel Santos' government to gain political support and to rival the "warmongering" news 
agenda until then prevalent, which presented FARC and other guerillas as terrorist organizations that had to be subdued militarily. The peace and warmongering journalism dichotomy identified by Barajas followed to a large extent the discourses of the two most important politicians of this period, Santos, and Uribe, respectively.

The negotiation between the Colombian government and FARC was kept secret for at least two years until it was leaked and then officially confirmed in September of 2012. This secrecy persisted in the official phase of Habana's peace negotiation, which was conducted behind closed doors, and communications were limited to official statements and joint press conferences (Pombo, 2017). Segura and Mechoulan (2017) concur with Pombo in that while the secrecy was effective for advancing the negotiation, this decision had the unintended consequence of distancing the public from the process, and ended up contributing to the triumph of the opposition to the peace agreements in the Plebiscite of 2016. Largely, the negotiations proceeded without a cease fire, so that journalists had the difficult task of covering peace negotiations amidst a violent conflict.

García-Perdomo (2017) analyzed the peace and hate frames used by journalists and the public regarding the Colombian presidential campaign of 2014 in Twitter using supervised Machine Learning. This author identified that peace and hate were the two most common frames, the first was especially popular among the public, whereas journalists used the second more often.

Regarding the framing of the Colombian armed conflict, Juan David Cárdenas Ruiz (2015) examined the language used by domestic media to refer to the actors involved and evaluate the legitimacy of their actions and discourses. Meanwhile, Serrano (2012) argued that -contrary to what is claimed in some Colombian journalism manualsthe press coverage of the country's conflict has been far from neutral. She says that it has been extremely difficult for journalists to strive for neutrality considering the lack of independence of mainstream media, the government's efforts to impede journalists to access sources from their contenders and the overall lack of freedom of press. Lastly, Larraz Elorriaga (2017) examined the press coverage of 
the peace negotiations and reflected on what it meant for the public to see yesterday's enemies as collaborators in peace building.

\section{Methodology}

\section{Keywords network}

The keywords assigned by Razón Pública to its articles are relevant meta-data for quantifying how much coverage the magazine gave to FARC. In addition, by modeling a network of co-occurrent keywords (Halpin, 2013; Ruiz, 2018), it is possible to identify the main concepts of the magazine's framing of FARC.

The use of keywords in Razón Pública falls under Jacob (2004) definition of categorization as a mechanism for organizing information based on the perceived similarities of elements in a set. While classification involves establishing hierarchies of exclusive and non-overlapping classes, categorization is a more "creative" process in which multiple attributes are assigned and clusters of related elements emerge. As categorization is one of the framing strategies identified by Fairclough and Mădroane (2020), it is worth analyzing the keywords most connected to FARC in Razón Pública.

The preprocessing of keywords began by using the commas as delimiters, so that compound keywords, like "Estados Unidos" (United States) or "Álvaro Uribe Vélez", were not separated. Afterwards, capitalization was removed to ensure consistency. Using these processes, 7,890 unique keywords were obtained. Following Halpin (2013), keywords in the tail of the distribution (in this case 5,427 keywords that appeared once) were discarded to reduce computational load.

With the 2,463 remaining keywords, a network was created in $\mathrm{Gephi}^{2}$ in which each keyword was a node with a weight equal to its frequency in the dataset, and edges were used to indicate cooccurring keywords. Then the network's normalized betweenness centrality was calculated, a standard quantification of how connected

2 Gephi is an open source software for network analysis and visualization. 
nodes are in a network based on the shortest paths between them.

\section{N-grams analysis}

$\mathrm{N}$-grams are sequences of " $\mathrm{n}$ " consecutive words or characters not separated by spaces. Michel et al. (2011) argue that changes in the frequencies of $n$-grams in a time-lapse may evidence changing patterns in the language of large collections of texts, and that this technique is especially helpful as it is not constrained by scale as traditional humanistic research methods are. Based on an n-grams analysis of the official documentation of Habana's Peace Process, J. L. Suárez and Yadira Lizama-Mué (2020) concluded that the victims were not as central in the language of these documents as was claimed.

The most frequent n-grams of Razón Pública's articles dataset were identified using a Python script (version 3.6) with the libraries NLTK and Spacy for NLP. First, the texts were tokenized with the Spacy Spanish package. Sequentially, punctuation marks were filtered out, and stop words (prepositions, articles, and conjunctions) removed. In addition, Snowball Stemmer for NLTK was used to reduce words to roots, ignoring accents, capitalization, gender, number, and verb conjugation.

Afterwards, the data was processed to extract unigrams $(n=1)$, bi-grams $(n=2)$ and trigrams $(n=3)$. To center the analysis of the n-grams into the magazine's framing of FARC, I searched for instances that included "FARC", or other expressions that had the strongest connections to FARC in the keywords network, in the lists of the top 200 most used bi-grams and trigrams.

\section{LDA topic modeling}

Latent Dirichlet Allocation (LDA) is a topic modeling technique devised by Blei et al. (2003) for classifying unstructured corpus of natural language texts thematically. This technique is based on the premise that the latent topics of a collection of texts 
can be represented as distributions of words, and that documents in the corpus can be represented as a combination of these topics. The LDA Topic Model uses a sparse Dirichlet prior to calculate, through several iterations, the probabilities at which a word appears along each other word in the dataset in the same documents. After generating the LDA model, the researcher analyzed qualitatively if the topics lists of top terms had an interpretable semantic or discursive category.

The topic model was generated with a Python (version 3.6) script and the Gensim package. The methodology followed Maier et al. (2018) "good practice guide" for validating LDA topic modeling in communication research, and addressed the major methodological challenges of using LDA identified by them. Based on Maier et al. (2018), multiple candidate models were generated with different configurations for the number of topics $(k)$ and $\alpha$ prior parameters, then a final model (with 30 topics $\alpha$ set to 0.5 ) was selected based on UMass coherence scores, topics Rank1 and the interpretability of its lists of top terms with the relevance parameter set to 0.6 and 1.0 (the overall model was presented with more detailed in Calderón Reyes, 2019).

The analysis of the LDA topic model focused on Topic 6 and Topic 7, the two topics that included FARC in its 30 top terms with the relevance parameter set to 1.0. Considering that the purpose of this article is to analyze Razón Pública framing of FARC, it is relevant to focus the analysis on these two topics. After revising the semantics of the topics' top terms, I sampled the thirty articles with the largest concentration of these, read them, and analyzed their content, language, and how they referred to FARC.

\section{Results and Discussion}

\section{Keywords network}

The prevalence of the keyword "farc" in this network is evident by reviewing the nodes with the highest betweenness centrality in Table 1. The keyword "farc" has the highest betweenness centrality, 
frequency, and tags in $13 \%$ of the articles in the dataset. The standardized betweenness centrality of this keyword is at least five points higher than those of the terms that appear closest to it -such as "bogotâ", "estados unidos", "colombia" and "juan manuel santos"and the frequency of this term is the highest in the dataset, being sixteen standard deviation above the network's average. Based on these statistics, it may seem that FARC was the magazine's main topic. Nevertheless, this may not be the case because keywords categorization is a subjective, context-dependent, and flexible organization scheme (Jones, 2004). For example, it makes sense that Bogotá is one of the most used keywords because it identifies articles with a local theme, a salient trait in a magazine dedicated to national current affairs. For this same reason, it is odd that Razón Pública even uses Colombia as a keyword; in this specific context, it would be more appropriate to only use countries other than Colombia, the magazine's de facto frame of reference.

\section{Table 1}

\section{Top 9 keywords by highest betweenness centrality}

\begin{tabular}{c|l|c|c|c|c|c}
\hline Position & \multicolumn{1}{|c|}{ Label } & C & M & BC & SC & SBC \\
\hline 1 & farc & 600 & 4 & 0.10 & 23.50 & 22.52 \\
\hline 2 & bogotá & 345 & 3 & 0.08 & 13.34 & 17.34 \\
\hline 3 & estados unidos (United States) & 347 & 1 & 0.07 & 13.41 & 17.18 \\
\hline 4 & colombia & 119 & 1 & 0.07 & 4.33 & 15.34 \\
\hline 5 & juan manuel santos & 255 & 2 & 0.06 & 9.75 & 13.45 \\
\hline 6 & corrupción (Corruption) & 232 & 3 & 0.05 & 8.83 & 12.26 \\
\hline 7 & corte constitucional (Constitutional Court) & 178 & 8 & 0.04 & 6.68 & 9.58 \\
\hline 8 & álvaro uribe vélez & 337 & 2 & 0.04 & 13.02 & 9.25 \\
\hline 9 & hernando gómez buendía & 246 & 2 & 0.03 & 9.39 & 6.33 \\
\hline
\end{tabular}

$\mathrm{C}=$ count, $\mathrm{M}=$ modularity class, $\mathrm{BC}=$ betweenness centrality, $\mathrm{SC}=$ standardized count, $\mathrm{SBC}=$ standardized betweenness centrality.

For this article, it is worth focussing the analysis on the keywords to which FARC is most densely connected to. Being the most used keyword in the magazine, it is not surprising that FARC is also the 
central node of one of the largest modules in network (Module 3), which encompasses $14,72 \%$ of the total keywords. The keyword FARC has a count ten times higher than the other main historical actors of the country's war: ELN, paramilitaries, and the Colombian armed forces; and even less frequent were keywords related to more recent actors, such as criminal bands (BACRIM). It is remarkable that, while the Colombian conflict is so complex; the magazine has focussed so much on FARC, to the extent that the other guerrilla groups (ELN), paramilitaries and the Colombian army seem to appear like mere supporting actors.

Medófilo Medina, historian, professor emeritus of the National University of Colombia and founding member of Razón Pública, is an important node in this module because he has authored numerous articles on FARC and has been referenced in many more.

\section{Table 2}

\section{Module 3 top terms by betweenness centrality}

\begin{tabular}{c|l|r|r|r|c}
\hline $\mathbf{R}$ & \multicolumn{1}{|c|}{ Keyword } & \multicolumn{1}{c|}{ C } & \multicolumn{1}{c|}{ BC } & SC & SBC \\
\hline 1 & farc & 600 & 0.41 & 25544 & 17.3 \\
\hline 2 & conflicto armado & 202 & 0.09 & 8600 & 3.8 \\
\hline 3 & proceso de paz & 133 & 0.10 & 5662 & 4.1 \\
\hline 4 & víctimas & 115 & 0.07 & 4896 & 3.0 \\
\hline 5 & paz & 95 & 0.03 & 4044 & 1.2 \\
\hline 6 & paramilitares & 64 & 0.03 & 2725 & 1.2 \\
\hline 7 & justicia transicional & 85 & 0.03 & 3619 & 1.2 \\
\hline 8 & acuerdo de paz & 108 & 0.02 & 4598 & 0.8 \\
\hline 9 & medófilo medina & 144 & 0.02 & 6130 & 0.8 \\
\hline 10 & derechos humanos & 163 & 0.03 & 6939 & 1.2 \\
\hline 11 & posconflicto & 61 & 0.03 & 2597 & 1.0 \\
\hline 12 & eln & 66 & 0.04 & 2810 & 1.4 \\
\hline 13 & violencia & 129 & 0.02 & 5492 & 0.8 \\
\hline 14 & guerrilla & 32 & 0.01 & 1362 & 0.4 \\
\hline 15 & militares & 45 & 0.01 & 1916 & 0.2 \\
\hline
\end{tabular}

$\mathrm{R}=$ rank by betweenness centrality, $\mathrm{C}=$ count, $\mathrm{BC}=$ betweenness centrality, $\mathrm{SC}=$ standardized count, $\mathrm{SBC}=$ standardized betweenness centrality. 
Based on the keywords that appear in Module 3, the magazine's staff markedly framed FARC in terms of armed conflict ("conflicto armado", "violencia") and peace ("proceso de paz", "paz", "acuerdo de paz"). In contrast, the alternative terms to name the armed conflict ("guerra", "guerra civil" and "terrorism") are not to be found among most strongly connected to FARC. The module also hints to a framing of the Colombian government- FARC negotiations focused on human rights, victims, and transitional justice. This is an important finding that, specially if the other methods point to similar result, would mean that the magazine's articles tended to align with the peace agreement official claim of putting victims at the center.

\section{N-grams}

$\mathrm{N}$-grams frequencies provided a basis for exploring the immediate contexts in which the terms FARC, peace and conflict were most frequently used. As a starting point, "farc" was the fifty-second highest frequency in the articles' dataset, appearing a total of 4127 times, and 23,1\% of the documents in the dataset contained this uni-gram at least once. The n-grams count put in perspective that, despite FARC being the single most used keyword, around three to fourths of the Razón Pública's articles don't even mention it.

In the list of top unigrams, "paz" (peace) appeared in the twenty-sixth position, and had a total count of 5493, considerably higher than that of FARC. Peace is usually referred as a goal to be attained by negotiation, as can be inferred from the most frequent bi-grams containing it: "proces paz" (peace process, $\mathrm{N}=781$ ), "acuerd paz" (peace agreement, $\mathrm{N}=525$ ), "justici paz (justice peace, $\mathrm{N}=217$ ), "negoci paz" (negotiation peace, $\mathrm{N}=177$ ), expressions present in FARC's module in the keywords network. The majority of the trigrams containing peace likely refer to the content or development of the Final Agreement to End the Armed Conflict and Build a Stable and Lasting Peace of 2016: "jurisdiccion especial paz" (special peace jurisdiction, $\mathrm{N}=65$ ), "firm acuerd paz" (signing peace treaty, $\mathrm{N}=59$ ), "paz establ durader" (stable and long lasting peace, $\mathrm{N}=57$ ), "proces 
paz farc" $(\mathrm{N}=45)$, "marc juridic paz" $(\mathrm{N}=45)$, "acuerd paz farc" $(\mathrm{N}=$ 44), "implement acuerd paz" ( $\mathrm{N}=34)$, "especial paz jep" ( $\mathrm{N}=32)$, "paz gobiern farc" $(\mathrm{N}=30)$, "acuerd paz gobiern" $(\mathrm{N}=27)$.

The most frequent $\mathrm{n}$-grams that included the root "conflict" $(\mathrm{N}=3,985)$ were "conflict armad" $(\mathrm{N}=983)$, "conflict intern" $(\mathrm{N}=$ 212), "conflict armad colombian" $(\mathrm{N}=43)$, whereas the most frequent n-grams with "guerr" (war, $\mathrm{N}=3,692)$ were "guerr civil" $(\mathrm{N}=182)$, "segund guerr mundial" (Second World War, N=81) and "primer guerr mundial" (First World War, $\mathrm{N}=29$ ). The counts for the unigrams "guerr" and "conflict" showed that these were used with a similar frequency overall. The term "guerr civil" appeared in a higher frequency than "conflict intern", but the results did not include a trigram that indicated the contexts most frequently referred to as civil wars. In contrast, the trigram "conflict armad colombian" establishes an explicit relation between "armed conflict" and the Colombian context.

Various of the top trigrams that contain "conflict" echo the recommendations the of the UNDP 2003 Colombia Report. Specifically, Chapter 14 of the Colombia Report proposes that the country needs an informative coverage of the armed conflict that contextualizes the public, analyzes possible solutions -both military and negotiated-and focussed on victims. The same expressions used to formulate these recommendations appeared in the following top trigrams that contained "conflict": "victim conflict armad" $(\mathrm{N}=41)$, "fin conflict armad" ( $\mathrm{N}=33)$, "sal negoci conflict" ( $=29)$, "context conflict armad" $(\mathrm{N}=28)$.

Recapping, both the n-grams and the keywords network results show that Razón Pública's consistently categorized the Colombian case as an armed conflict instead of a war. In addition, the n-grams analysis suggests that the magazine analyzed the Peace Negotiations of Habana using a language like that presented in the process official documents. This similarity does not imply that most of the articles supported the process necessarily. Still, the extent to which their top terms coincide can be interpreted as a sign that, at an aggregated level, the magazine's articles framed their conception of the ongoing conflict and the tentative peace in a language close 
to that registered in the Final Peace Agreement and its official documentation. Moreover, as some of the articles top n-grams echoed the main recommendations of the UNDP Colombia Report of 2003 for supporting a durable and stable solution to the conflict.

\section{LDA topic model results}

The LDA model indicates that FARC was most frequently framed in Razón Pública as an actor in a peace process (Topic 7), and, to a considerably lesser extent, as an actor of the Colombian armed conflict and drug trafficking (Topic 6). The estimated frequency of FARC was considerably higher in Topic 7 (of 0.028) than in Topic 6 (0.007), so while both topics are firmly connected to FARC, the relationship between Topic 7 and FARC is much stronger. Still, to understand how these two topics frame FARC, a qualitative interpretation of the topics lists of top terms and of the sixty articles with the highest concentration of these.

The most representative articles of Topic 6 and Topic 7 sampled were written or co-written by forty different authors. Largely, these authors, all of whom are named in the next subsection, are researchers and academics connected to institutions located in Colombia. For most of these authors, one article was drawn. The author with the most articles sampled was Kyle Johnson, with eleven publications. Between 2010 and 2018, Johnson worked as researcher for multiple organizations in Colombia, among them Corporación Nuevo Arco Iris, UN Migration and International Crisis Group (Johnson's LinkedIn Profile, 2021). With five articles each, the next authors with the most articles sampled were: Álvaro Villarraga, director of Fundación Cultura Democrática and professor (Villarraga's Razón Pública's profile, 2021), and Christian Voelkel, former ProPaz coordinator for Transitional Justice and also a former researcher of International Crisis Group (Voelkel's LinkedIn Profile, 2021). The articles written by Villarraga, Johnston and Voelkel, respectively, nineteen, sixteen and six, constitute a small subset of the articles' dataset. The high frequency at which the articles by these authors 
were sampled means that they tended to focus on deciphering how to solve the conflict between the Colombian Government, FARC and other armed factions. The topic composition of articles by Johnston and Voelkel, both analysts of the International Crisis Group, shows that they abstained from commenting on electoral politics and international affairs.

None of the sixty articles by Medófilo Medina were sampled despite that he was the most central author in FARC's keywords module, and that he examined FARC's peace process in numerous articles. Overall, his articles had a more heterogenous topic composition, with notorious concentrations of Topic 1 (electoral politics), Topic 3 (culture), and Topic 4 (international conflicts), and also Topic 7 .

As mentioned in the methodology, the sole criterion for sampling the articles read was their topic composition in the final LDA model. The fact that so many different authors appeared shows some degree of diversity of perspectives. At the same time, Johnston, Villarraga and Voelkel were leading voices on issues related to FARC, and that their texts tend to exemplify the language used in Razón Pública to decipher the guerrilla group as an actor in terms of war and peace.

Topic 7: Peace process framing. Topic 7 focuses on peace negotiations, and is presented first because it has the strongest connection to FARC. In addition to having "paz" as its top term, most other tops terms are related to the semantic field of peace negotiation ("negoci", "acuerd", "proces", "particip"), to the specific context and actors of recent peace processes in Colombia ("gobiern", "guerrill", "haban", "sant"), or, to a lesser extent, to the opposite semantic field of war ("conflict", "armas", "armad", and "guerr"). 


\section{Table 3}

\section{Topic 6 and Topic 7 top terms with estimated frequency distribution (relevance parameter set to 1.0)}

\begin{tabular}{|c|c|c|}
\hline $\begin{array}{c}\text { Topic } \\
\text { number }\end{array}$ & $\begin{array}{c}\text { Size } \\
\text { (as \% } \\
\text { tokens }\end{array}$ & Top 30 terms \\
\hline 6 & 5.1 & 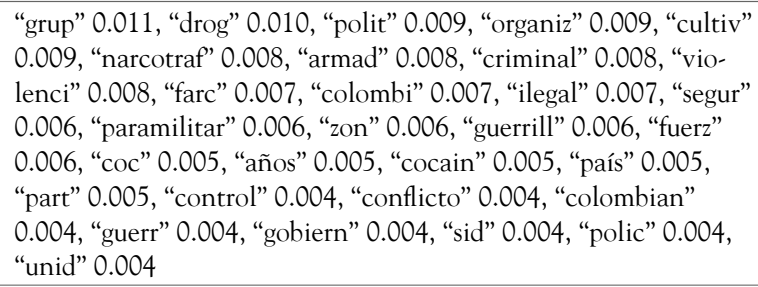 \\
\hline 7 & 4.7 & 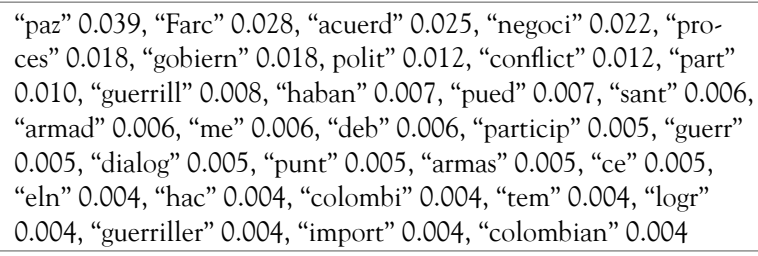 \\
\hline
\end{tabular}

The thirty articles with the highest concentration of Topic 7 discussed Colombian peace processes and negotiations. These articles recurrently addressed the obstacles and challenges of the peace process, and frequently acknowledged the progress made to de-escalate the conflict.

As a representative example of the language of Topic 7, in the following quote Christian Voelkel (2015) recognized the advances of FARC and the Colombian government regarding the negotiation of terms for verification of the cease fire: "Las negociaciones de paz entre el gobierno y las FARC salieron de su crisis más profunda mediante un acuerdo que se ha anunciado el domingo pasado para "des-escalar" el conflicto y acelerar las negociaciones" (2015, italic letters added by the researcher to indicate the topic's top terms).

Thirteen of the articles with the highest concentration of Topic 6 focused on the Habana peace process between the Colombian government and FARC. Overall, these documents discussed the development of the negotiations in terms of the progress made as well as the obstacles, risks and uncertainties. The negotiation and 
verification of a ceasefire was discussed throughout the process, initially as a unilateral decision by FARC (Garzón, 2012; Nasi, 2012), and later as a fundamental bilateral condition for concluding the negotiation (Borrero, 2015; Restrepo \& Nieto, 2016; Villarraga, 2015b). A recurrent consideration in these analysis was the impact of the negotiations in contributing to a de-escalation of the armed conflict (Dávila, 2015) and the importance of setting credible mechanisms for verifying the agreement, especially in terms of arms surrender and demobilization (Johnson, 2016; Voelkel, 2015). Lastly, two articles -both authored by Aguirre (2017a, 2017b)- followed-up the implementation of the Peace Agreements, criticizing the Santos' Government's neglect and delays in complying its part after FARC's demobilization.

Fourteen of the articles sampled for Topic 7 centered in the peace talks between the Colombian government and Ejército de Liberación Nacional (ELN): B. Duarte (2010), C. Medina (2013), Zuluaga (2013, 2018), Voelkel (2014, 2015a, 2015b) and Johnston (2016a, 2016b, 2016c, 2017a, 2017b, 2017d, 2018a). Albeit these articles focused on ELN, they frequently contained references and comparisons to the FARC peace process, and some even discussed the possibility of ELN joining the FARC-Government agreement. Interestingly, while ELN had a lower estimated frequency in Topic 7 than FARC, half of the articles with the highest concentration of the topic were centered in the inconclusive Government-ELN dialogues. In addition, the latter articles on the ELN peace process tended to be more skeptical because the guerrilla did not seem to have a clear agenda and the deep mistrust between them and the government. The remaining two articles differed from the others in that they offered historical reflections on the lessons that can be learned from the previous peace process in Colombia (Garzón, 2012; Villarraga, 2012).

All of the aforementioned articles use a similar language to analyze the developments of the peace process in Colombia, their repercussions and prospective scenarios, and sought to examine the interests and rationales of the actors involved in peace negotiations to elucidate their intentions, motives, and have realistic expectations of possible negotiated solutions. 
Topic 6: Armed conflict and drug trafficking framing. Topic 6's top terms gravitate towards the semantic fields of criminality and drug trafficking, as the apparition of the term "drog" (drugs), "narcotraf", "cultiv" (crops), "violenci", "cocain". In addition to "farc" and "guerrill", this topic has top terms that refer, at various levels of specificity, to the actors of Colombia's war: "paramilitar", "polic", "gobiern", "grup", "organiz" (organization), "criminal". The following quote, from an article by Boris Salazar (2015), constitutes a representative example of Topics 6, in which we can see several of its top terms being used to present an analysis of the rising threat of new criminal gangs in Colombia's major cities:

La transición desde un mundo dominado por la guerra contra las drogas y la guerrilla -el narcoterrorismo que todo lo hacía más fácil- a un mundo hecho de miles de organizaciones criminales, ligadas entre sí, por organizaciones violentas que ejercen un control armado y territorial sobre ellas, con una cantera casi inagotable de jóvenes socializados en la ilegalidad, es un desafío inmenso para el Estado, la policía, y una justicia, todos ellos adaptados a la guerra contra las drogas y la guerrilla.

In another article, García Duarte (2010) examined the repercussions of the death of Mono Jojoy in FARC's strategies, and concluded that, despite this devastating blow, FARC was able and likely to prolong a defensive war over multiple zones. A considerable portion of the articles with the highest concentrations of Topic 6 discussed the use of violence by armed organizations other than FARC and ELN to enforce territorial control. Restrepo (2011), Reeds (2012), Alarcón (2015), Arocha (2017) warned about the rise of Criminal Bands (BACRIM) and similar organizations linked to paramilitarism and drug trafficking that could trigger a new wave of violence.

The disputes between criminal organizations over control of Colombian territories and drug routes was a crucial issue in various of Topic's 6 articles. Johnson (2011) examined the armed confrontation between FARC and ERPAC's - a criminal group established by former paramilitaries. The power vacuum left by FARC's demobilization and the territorial rearrangement of the actors of the conflict and criminal groups was examined by Álvarez (2016) in the Catatumbo 
region, Restrepo (2018) and Johnston (2018b) wrote similar analyses about the municipality of Tumaco. Salazar (2015) and Restrepo (2017), considered the expansion of criminal bands at a national level. Similarly, Duarte and Betancur (2017) argued that a civil war continued in multiple territories after FARC's demobilization, Johnson (2017c) warned that it was likely that some FARC dissidences remained after the peace process, Salazar (2017) argued that the social conditions in multiple regions remained unchanged after the Peace Agreement, and Guevara (2018) warned about the persecution of social leaders after the Peace Agreement.

While the articles previously mentioned focused on the strategies for dealing with drug trafficking, others focused on assessing current or hypothetical public policies on this issue. Restrepo (2016) held that Habana's Peace Process had been good for the drug trafficking business, as the de-escalation of the conflict enabled multiple groups to dedicate their efforts in increasing their crops. Uribe (2016a) argued against a proposal to have the Colombian government to buy all of the coca production to deprive drug cartels of the raw material, and, in a latter article (2016b), added that adopting a public policy of state presence in the territories is the only effective way to stop coca production. Zuleta (2017) analyzed the failures of the crop substitution policies and concluded that it was attributed to the continuation of violence and territorial disputes of criminal groups. Meanwhile, Garzón and Suárez (2017) reflected that the acceleration of forced eradication after the peace process did not diminish the cultivated area and had exacerbated the conflict. While most of Topic 6 articles focused on the drug trafficking and crops in Colombia, Moreano and Noboa (2018) analyzed its repercussions in the border with Ecuador, and Bagley (2011a) argued that the global War Against Drugs was being lost because while multiple cartels had been destroyed, these had always been succeeded by other organizations that relocated crops and established new routes.

The remaining articles presented longitudinal analysis, such as Valencia (2010) overall balance of Alvaro's Uribe's two terms, Duncan (2017) historical overview of drug trafficking in Colombia and the cartels' strategies, Villarraga (2017) discussed the history of 
dissidences in the Colombian guerrillas, and Bagley (2011b) presented a brief history of the Latin American drug cartels. Additionally, Melo (2008) and Sánchez (2013) analyzed the country's statistics of violent deaths, and proposed analysis of this data regarding the intensity of armed conflict in the last fifty years.

Altogether, the articles with the highest concentration of Topic 6 discussed drug trafficking, violent conflict between armed actors over territorial control, the relations between both phenomena, and assessed existing or hypothetical public policies on these issues. A handful of the articles sampled that focused on FARC's military strategy framed FARC as an active actor of the armed conflict. More frequently, FARC was presented as an armed actor whose demobilization opened opportunities for criminal groups to expand their territories and drug routes. In this regard, the recurrent use of "criminal" and derived expressions, such as BACRIM, to refer to FARC's supplanters in Topic 6 connotes, as identified by Giraldo (2009, p. 284), an attempt to deny the possibility of war to those who fight against a state.

\section{Negotiation, armed conflict and drug trafficking frames through time}

In addition to detecting recurrent semantic relations in a corpus and sampling documents accordingly, LDA topic modeling enables researchers to quantify the fluctuations of the coverage of each topic over time. Overall, Topic 6 and Topic 7 have similar sizes as the estimated percentage of tokens in the dataset $(5,1 \%$ and $4,7 \%$ respectively), yet there were considerable bi-annual fluctuations.

Figure 1 shows that in the first four years of Razón Pública (before the announcement in September of 2012 of an official FARC-Government peace process), Topic 6: armed conflict and drug trafficking had more coverage than Topic 7: peace negotiations. In the time between the negotiation's announcement and the second half of 2016, Topic 6 received more coverage, and peaked when agreement was signed in the second half of 2016. In the last three terms, it is noticeable that the peace topic fell to a level close to that of the 
pre-negotiation period, an interesting result that indicates that the peace agreement implementation and follow up did not receive as much coverage as the peace talks.

FARC's topics biannual sizes (as \% of tokens in the dataset)

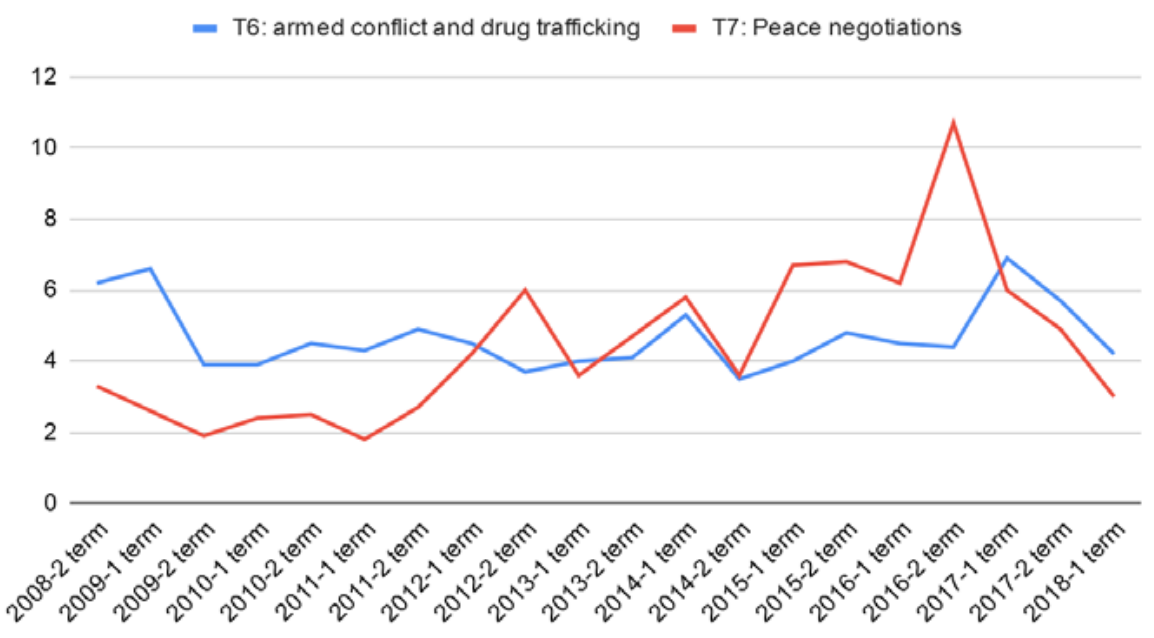

Figure 1. FARC's topics' biannual sizes.

By tracking which were the first articles focused on Topic 7, I found three that stand out for foreseeing a peace process between Santos' Government and FARC long before it was officially announced. In the first of these, Congote (2010) examined the rationales of FARC's and the political establishment and concluded that the main obstacle to bringing these parties together was a fear of negotiation entrenched in the country's political culture. Likewise, Palou (2010) considered that Santos's discourse and early actions indicated a disposition to dialogue and considered that a popular misconception is that the armed and negotiated solutions are mutually exclusive. With remarkable foresight, María Victoria Duque (2010) even recognized that FARC and the Government were both equally interested in negotiating, and referred to it as "No es fácil, no es imposible" (It is not easy, it is not impossible). A phrase 
that is, probably, the most representative of Razón Pública's framing of the peace negotiations as extremely complex and worthwhile.

Gradually, more authors agreed that the a peace negotiation with FARC was likely before it was officially announced, among them M. Medina (2011), Herbolzheimer (2011), González (2011), Chamat (2011), L. F. Medina (2012) and Buendía (2012).

Finally, regarding the decline of Topic 7 after 2016, the article "Estamos cansados de la paz" (2017), by Gómez Buendía, analyzed the shift in political priorities after FARC's demobilization. This article explained the diminishing coverage of the frames associated with FARC at the end of the studied period. In this article, the magazine director said that the only national project of contemporary Colombia had been the elimination of FARC as a guerilla and the violence caused by them, and now that this was achieved, most people would lose interest in the peace agreements.

\section{Conclusions}

In the decade studied, Razón Pública centered its coverage of FARC on analyzing its agenda, motivations, and rationale as a protagonist of the country's armed conflict, drug trafficking, and, especially, peace processes. The analysis of the keywords network and of the top n-grams showed that, while multiple authors wrote about FARC in Razón Pública, the magazine consistently framed FARC in terms of peace and armed conflict. This categorization frame may have resulted from a consensus among the authors in terms of how they viewed FARC, or it may have been due to Razón Pública's editorial line.

In the two LDA topics most strongly connected to FARC, we can see Razón Pública's equilibrium between analyzing the feasibility of violence de-escalation via negotiations, acknowledging the processes' complexity, and obstacles and uncertainties, and developing a longterm critical assessment. In the peace negotiations frame, FARC was the protagonist, along with ELN and the Colombian government. By contrast, in terms of the magazine's framing of the armed 
conflict, FARC was one among many factions that participated in it. Moreover, as the negotiations matured, FARC appeared more often as a passive actor in the conflict, whose eventual demobilization presented an opportunity for criminal organizations to expand their territories with the acquiescence of the State.

Although Razón Pública persistently categorizes Colombia's war as an "armed conflict, the magazine's framing of FARC echoed Giraldo's "caminos sin alegría" (joyless roads) (2009). The latter acknowledged that FARC's demobilization required a combination of military and negotiated solutions, with some authors even foreseeing the start of the peace process with cautious optimism. Considering the secrecy of the peace negotiations (Pombo, 2017; Segura \& Mechoulan, 2017) and the opacity of Colombia's war, Razón Pública's analysis provided its public with a contextualized and insightful perspective on the tricky prospects of negotiating peace amidst a persistent war. This study shows that, overall, Razón Pública aligned with the spirit of the negotiation itself, supporting it firmly while keeping a critical distance from the Colombian government and FARC.

This article shows how some authors of Razón Pública disarmed, figuratively, FARC by deciphering the group's complex rationale for engaging war and peace, and framing its new raison d'etre as one devoted to solving conflicts through negotiations, which would be its normal modus operandi as a political party in a democratic system. Suárez and Lizama-Múe (2021) argued that a foundational language for Colombia's peace was created at Habana's Negotiation Table. Concurrently to these peace negotiations, this case study on Razón Pública showed that its pool of analysts and researchers contributed to formulate a similar language to analyze the country's conflict and propose solutions. The expression "stable and long-lasting peace" at the heart of the Final Peace Agreements can be traced back to the UNDP 2003 Report "firm and long-lasting peace" (p. 471), and also appeared among Razón Pública's top trigrams. Some authors, among them Congote, Palou and Duque, started deciphering that a negotiated solution to demobilize FARC was becoming more feasible long before the negotiation's official announcement. The magazine's framing of FARC centered on examining the development, 
challenges, and implications of the peace negotiations, and, to a lesser degree, FARC's participation in the armed conflict and drug trafficking. The results can be viewed as an answer to the UNDP Colombian Report's (2003) call for analytic journalism that improves the public's understanding of the country's complex armed conflict and its possible negotiated and military solutions.

Revisiting this article in early March 2021, Habana's Peace Agreement achieved the demobilization of FARC, although, some dissident groups stayed in arms as was expected. Still, the persistence of massacres, killings of social leaders, combats over territories and drug trade and multiple other forms of violence means that the promise of a stable and long-lasting peace remains unfulfilled. The language frames used to conceive a negotiated solution to FARCColombian Government took many years to develop, and this article showcases the contributions of an independent magazine to this discursive construction. Unfortunately, this negotiation frame seems inadequate to disarm the country's contemporary wars. Now, there is more opacity regarding the factions involved, their intentions, strategies and weaknesses in comparison to what was known about FARC in the period 2010-2016 I

\section{References}

Aguirre, K. (2017a, marzo 6). La dejación de armas de las FARC: incertidumbre y retrasos. Razón Pública. https://razonpublica.com/ladejacion-de-armas-de-las-farc-incertidumbre-y-retrasos/.

Aguirre, K. (2017b, mayo 22). Llegó el Día D+180 y no se cumplieron los tiempos de la paz. Razón Pública. https://razonpublica.com/llego-eldia-d-180-y-no-se-cumplieron-los-tiempos-de-la-paz/.

Alarcón Gil, C. (2011, diciembre 5). La hidra multicéfala: a propósito de la socialización y la captura de narcotraficantes. Razón Pública. https://razonpublica.com/la-hidra-multicefala-a-proposito-de-lasocializacion-y-la-captura-de-narcotraficantes/. 
Alarcón Gil, C. (2015, mayo 3). El Estado colombiano frente a las organizaciones criminales. Razón Pública. https://razonpublica.com/elestado-colombiano-frente-a-las-organizaciones-criminales/.

Álvarez Vanegas, E. (2016, mayo 16). 5. El Catatumbo: reacomodo de la guerra y tensiones sociales. Razón Pública. https://razonpublica.com/ el-catatumbo-reacomodo-de-la-guerra-y-tensiones-sociales/.

Álvarez Vanegas, E. (2017, enero 16). El crimen organizado en el nivel local: ¿un problema subvalorado en Colombia? Razón Pública. https://razonpublica.com/el-crimen-organizado-en-el-nivel-local-unproblema-subvalorado-en-colombia/.

Arocha, M. F. (2017, mayo 16). El Clan del Golfo: la gran amenaza para la seguridad en el posconflicto. Razón Pública. https://razonpublica. com/el-clan-del-golfo-la-gran-amenaza-para-la-seguridad-en-elposconflicto/.

Bagley, B. (2011a, enero 31). El "efecto globo" o por qué se está perdiendo la "Guerra contra las Drogas". Razón Pública. https://razonpublica. com/el-efecto-globo-o-por-que-se-esta-perdiendo-la-guerra-contra-lasdrogas/.

Bagley, B. (2011b, febrero 21). Carteles de la droga: de Medellín a Sinaloa. Razón Pública. https://razonpublica.com/carteles-de-la-droga-demedellin-a-sinaloa/.

Barajas, H. (2016). Peace journalism - A panacea for post-conflict Colombia? Panorama, 10(18), pp. 121-135. https://antilagom.files. wordpress.com/2016/02/peace-journalism-a-panacea-for-post-conflictcolombia-docx.pdf.

Blei, D. M., Ng, A. Y., \& Jordan. M. I. (2003). Latent Dirichlet Allocation. Journal of Machine Learning Research, (3), 993-1022. https://bit. ly/31MgUbV.

Blondel, V. D., Guillaume, J.-L. Lambiotte, R., \& Lefebvre, E. (2008). Fast unfolding of communities in large networks. Journal of Statistical Mechanics: Theory and Experiment (10), 1-12. DOI: 10.1088/17425468/2008/10/P10008. 
Borrero, A. (2015, enero 18). Cese bilateral del fuego: ¿oportunidad u obstáculo? Razón Pública. https://razonpublica.com/cese-bilateral-delfuego-oportunidad-u-obstaculo/.

Brüggemann, M. (2014). Between frame setting and frame sending. How journalists contribute to news frames. Communication Theory, 24(1), 61-82. https://doi.org/10.1111/comt.12027.

Buendía, H. G. (2012, marzo 11). Las FARC quieren negociar. Razón Pública. https://razonpublica.com/las-farc-quieren-negociar55/.

Calderón Reyes, E. (2019). Public Interest in Razón Pública: A Data-driven Network Analysis. (6796). [Master's Thesis, University of Western Ontario]. https://ir.lib.uwo.ca/etd/6796.

Cárdenas Ruiz, J. D. (2015). Los medios de comunicación como actores (des) legitimados. Algunas reflexiones acerca del rol de los medios de comunicación sobre la construcción de la opinión pública en torno al Proceso de Paz de la Habana. Análisis Político, 28(85), 38-56. https:// dx.doi.org/10.15446/anpol.v28n85.56245.

Chamat, N. (2011, agosto 27). Para alcanzar la paz: "Seamos razonables, exijamos lo imposible". Razón Pública. https://razonpublica.com/paraalcanzar-la-paz-seamos-razonables-exijamos-lo-imposible/.

Congote, B. (2010, noviembre 8). No negociar con las FARC: ¿Un absurdo? Razón Pública. https://razonpublica.com/no-negociar-con-las-farc-iunabsurdo/.

Dávila, A. (2015, junio 8). ¿En qué van el desminado y el des-escalamiento del conflicto? Razón Pública. https://razonpublica.com/en-que-van-eldesminado-y-el-des-escalamiento-del-conflicto/.

DiMaggio, P., Nag, M., \& Blei D. (2013). Exploiting affinities between topic modeling and the sociological perspective on culture: Application to newspaper coverage of U.S. government arts funding. Poetics, (41), 570-606. DOI: 10.1016/j.poetic.2013.08.004.

Duarte, B. (2018, febrero 12). Mesa de Quito: falta de voluntad y capacidad para alcanzar la paz. Razón Pública. https://razonpublica.com/mesa-dequito-falta-de-voluntad-y-capacidad-para-alcanzar-la-paz/. 
Duarte, C., \& Betancourt, D. (2017, agosto 21). Los territorios que dejaron las FARC: ¿cómo se vive bajo una paz incompleta? Razón Pública. https://razonpublica.com/los-territorios-que-dejaron-las-farc-como-sevive-bajo-una-paz-incompleta/.

Duncan, G. (2017, septiembre 11). De la ciudad al campo: los tránsitos del negocio de la droga en Colombia. Razón Pública. https://razonpublica. com/de-la-ciudad-al-campo-los-transitos-del-negocio-de-la-droga-encolombia/.

Duque, M. V. (2010, noviembre 22). La paz, una oportunidad para Santos. Razón Pública. https://razonpublica.com/la-paz-una-oportunidad-parasantos/.

Entman, R.M. (1993). Framing: TowardClarification ofa Fractured Paradigm. Journal of Communication, (43), 51-58. doi:10.1111/j.1460-2466.1993. tb01304.x.

Fairclough, I., \& Mădroane, I. (2020). Aproximación argumentativa al "framing": enmarcado, deliberación y acción en un conflicto ambiental. Co-Herencia, 17(32), 119-158. https://doi.org/10.17230/coherencia.17.32.5.

Fundación Gabo para el Nuevo Periodismo (2019, octubre 18). La paz con los ojos abiertos: periodismo, comunicación y construcción de paz en Colombia. https://fundaciongabo.org/es/recursos/publicaciones/la-pazcon-los-ojos-abiertos-periodismo-comunicacion-y-construccion-depaz-en.

García Duarte, R. (2010, septiembre 27). ¿Qué sigue después de Jojoy? Razón Pública. https://razonpublica.com/ique-sigue-despues-de-jojoy/.

García-Perdomo, V. (2017). Entre paz y odio: Encuadres de la elección presidencial colombiana de 2014 en Twitter. Cuadernos.info, (41), 5770. https://dx.doi.org/10.7764/cdi.41.1241.

Garzón, J. C. (2012, noviembre 26). Cese unilateral y conversaciones en la Habana. Razón Pública. https://razonpublica.com/cese-unilateral-yconversaciones-en-la-habana/.

Garzón, J. C. (2012, septiembre 3). El pasado reciente está en Ralito, no en El Caguán. Razón Pública. https://razonpublica.com/el-pasadoreciente-esta-en-ralito-no-en-el-caguan/. 
Garzón, J. C., Suárez M. (2017, octubre 16). Erradicación forzada: los efectos de una meta sin sentido. Razón Pública. https://razonpublica. com/erradicacion-forzada-los-efectos-de-una-meta-sin-sentido/.

Giraldo Ramírez, J. (2009). Guerra civil posmoderna. Siglo del Hombre.

Giraldo Ramírez, J. (2015). Política y guerra sin compasión. En Comisión Histórica del Conflicto y sus Víctimas, Contribución al entendimiento del conflicto armado en Colombia (pp. 471-520). Desde Abajo. [Versión digital del Observatorio de $\mathrm{Paz}$ y Conflicto, Informes $\mathrm{CHCV}$, disponible en https://bit.ly/3dCghqL].

González, C. (2011, septiembre 26). La paz: ¿está llegando el momento? Razón Pública. https://razonpublica.com/la-paz-iesta-llegando-elmomento/.

Guevara, C. (2018, julio 9). Los líderes sociales y la suma de todos los miedos. Razón Pública. https://razonpublica.com/los-lideres-sociales-yla-suma-de-todos-los-miedos/.

Gutiérrez Sanín, F. y Sánchez, G. (2006). Prólogo. En Nuestra guerra sin nombre (pp. 8-19). IEPRI, Norma.

Halpin, H. (2013). The Semantics of Tagging. In Social Semantics, Semantic Web and Beyond (Computing for Human Experience), Vol. 13 (pp. $107-$ 147). Springer. https://doi.org/10.1007/978-1-4614-1885-6_5.

Herbolzheimer, K. (2011, julio 18). Viejos y nuevos procesos de paz. Razón Pública. https://razonpublica.com/viejos-y-nuevos-procesos-de-paz-/.

International Center for Transitional Justice (2016). Media and Transitional Justice: A Dream of Symbiosis in a Troubled Relationship. https://www. ictj.org/publication/media-transitional-justice-symbiosis-troubledrelationship.

Johnson, K. (2021). In LinkedIn (Profile). https://co.linkedin.com/in/kylejohnson-211b5313b.

Johnson, K. (2011, noviembre 21). FARC, ERPAC, Cuchillo y Caracho: un mundo de amenazas cruzadas. Razón Pública. https://razonpublica. com/farc-erpac-cuchillo-y-caracho-un-mundo-de-amenazas-cruzadas/. 
Johnson, K. (2016a, febrero 1). La misión de verificación de Naciones Unidas: ventajas y pendientes. Razón Pública. https://razonpublica. com/la-mision-de-verificacion-de-naciones-unidas-ventajas-ypendientes/.

Johnson, K. (2016b, febrero 29). ELN: tan cerca y tan lejos de la paz. Razón Pública. https://razonpublica.com/eln-tan-cerca-y-tan-lejos-de-la-paz/.

Johnson, K. (2016c, abril 11). La negociación con el ELN y la búsqueda de la paz completa. Razón Pública. https://razonpublica.com/la-negociacioncon-el-eln-y-la-busqueda-de-la-paz-completa/.

Johnson, K. (2016d, julio 11). ¿Por qué no arranca la paz con el ELN? Razón Pública. https://razonpublica.com/por-que-no-arranca-la-paz-con-eleln/.

Johnson, K. (2017a, enero 30). El oscuro futuro de la negociación con el ELN. Razón Pública. https://razonpublica.com/el-oscuro-futuro-de-lanegociacion-con-el-eln/.

Johnson, K. (2017b, junio 12). Negociación con el ELN: los tiempos del monte en la mesa de paz. Razón Pública. https://razonpublica.com/ negociacion-con-el-eln-los-tiempos-del-monte-en-la-mesa-de-paz/.

Johnson, K. (2017c, julio 3). Los disidentes de las FARC: ¿Cuántos son? ¿Cómo manejarlos? Razón Pública. https://razonpublica.com/ disidencias-de-las-farc-solo-estan-buscando-plata/.

Johnson, K. (2017d, diciembre 11). La negociación sin Restrepo ¿aceleración o estancamiento del diálogo con el ELN? Razón Pública. https://razonpublica.com/la-negociacion-sin-restrepo-aceleracion-oestancamiento-del-dialogo-con-el-eln/.

Johnson, K. (2018a, diciembre 11). ¿Tienen futuro las negociaciones con el ELN? Razón Pública. https://razonpublica.com/la-negociacion-sinrestrepo-aceleracion-o-estancamiento-del-dialogo-con-el-eln/.

Johnson, K. (2018b, abril 23). Tumaco: ¿la paz inalcanzable? Razón Pública. https://razonpublica.com/tumaco-la-paz-inalcanzable/.

Jacob, E. K. (2004). Classification and Categorization: A Difference that Makes a Difference. Library Trends, 52(3), 515-540. http://hdl.handle. net/2142/1686. 
Larraz-Elorriaga, I. (2017). La construcción de legitimidad a través del capital simbólico. El caso del proceso de paz de Colombia. Estudios Políticos, (50), 257-280. https://dx.doi.org/10.17533/udea.espo.n50a14.

Londoño, J. F. (2016, marzo 14). ¿Por qué se postergó la firma de la paz? Razón Pública. https://razonpublica.com/por-que-se-postergo-la-firmade-la-paz/.

Maier, D. A., Waldherr, P., Miltner, G., Wiedemann, A., Niekler, A., Keinert, B., Pfetsch, G., Heyer, U., Reber, T., Häussler, H., Schmid-Petri \& S. Adam (2018). Applying LDA Topic Modeling in Communication Research: Toward a Valid and Reliable Methodology. Communication Methods and Measures, 12(2-3), 93-118, DOI: 10.1080/19312458.2018.1430754.

Mantilla, J. (2012, julio 23). La apuesta geopolítica de las FARC en el Cauca ¿concentración o dispersión? Razón Pública. https://razonpublica. com/la-apuesta-geopolitica-de-las-farc-en-el-cauca-iconcentracion-odispersion/.

Márquez Díaz, J. (2014, junio 8). 50 años de las FARC: de Marquetalia a La Habana. Razón Pública. https://razonpublica.com/50-anos-de-las-farcde-marquetalia-a-la-habana/.

Medina, C. (2013, julio 15). El ELN en el recodo de la paz. Razón Pública. https://razonpublica.com/el-eln-en-el-recodo-de-la-paz/.

Medina, L. F. (2012, abril 9). ¿Qué falta para propiciar la paz? Razón Pública. https://razonpublica.com/ique-falta-para-propiciar-la-paz/.

Medina, M. (2011, octubre 3). Balance del gobierno Santos: Ni tanto que queme al santo ni... Razón Pública. https://razonpublica.com/balancedel-gobierno-santos-ni-tanto-que-queme-al-santo-ni/.

Melo, J. O. (2008, agosto 11). Cincuenta años de homicidios: tendencias y perspectivas. Razón Pública. https://razonpublica.com/cincuenta-adehomicidios-tendencias-y-perspectivas/.

Michel, J., Shen, Y., Aiden, A., Veres, A., Gray, K., Matthew, P., Pickett, J., Hoiberg, D., Clancy, D., Norvig, P., Orwant, J., Pinker, S., Nowak, M., \& Lieberman Aiden, E. (2011). Quantitative Analysis of Culture Using Millions of Digitized Books. Science, 331(6014), 176-82. DOI: 10.1126/science.1199644. 
Ministerio de Defensa Nacional de Colombia (2013, septiembre 24). Comandantes de Fuerza presentaron resultados operacionales de los últimos 2 años. https://bit.ly/3dybqXC.

Moreano, H. y Noboa, M. H. (2018, abril 23). Asesinatos, drogas y atentados: vuelve el terror del narcotráfico a la frontera colomboecuatoriana. Razón Pública. https://razonpublica.com/asesinatosdrogas-y-atentados-vuelve-el-terror-del-narcotrafico-a-la-fronteracolombo-ecuatoriana/.

Nasi, C. (2012, octubre 8). ¿Cese al fuego con las FARC? Razón Pública. https://razonpublica.com/icese-al-fuego-con-las-farc/.

Nasi, C. (2015, junio 22). La mala hora del proceso de paz: anatomía de la crisis. Razón Pública. https://razonpublica.com/la-mala-hora-delproceso-de-paz-anatomia-de-la-crisis/.

Newman, D. J. \& Block, S. (2006). Probabilistic topic decomposition of an eighteenth-century American newspaper. Journal American Society of Information Science, (57), 753-767. doi:10.1002/asi.20342.

Palou, J. C. (2010, noviembre 15). La política de paz, o la combinación de todas las formas de legalidad. Razón Pública. https://razonpublica.com/ la-politica-de-paz-o-la-combinacion-de-todas-las-formas-de-legalidad/.

Palou, J. C. (2015, abril 27). ¿Qué hubo -y qué sigue- tras el ataque guerrillero en el Cauca? Razón Pública. https://razonpublica.com/que-hubo-y-quesigue-tras-el-ataque-guerrillero-en-el-cauca/.

Pécaut, D. (2015). Un conflicto armado al servicio del statu quo social y político. En Comisión Histórica del Conflicto y sus Víctimas, Contribución al entendimiento del conflicto armado en Colombia (pp. 627-678). Desde Abajo.

Pizarro Leongómez, E. (2015). Una lectura pluralista y múltiple de la historia. Comisión de Historia del Conflicto y sus Víctimas, Centro de Memoria Histórica. https://bit.ly/3dJMtbY.

Pombo García, N. (2017). Periodismo y procesos de paz: reflexión comparativa en el cubrimiento de negociaciones de paz en Colombia entre el gobierno y las FARC-EP. [Tesis de Maestría, Universidad Colegio Mayor de Nuestra Señora del Rosario]. http://repository.urosario.edu.co/ handle/10336/13971 
Qué es Razón Pública (2009, octubre 26). Razón Pública. https:// razonpublica.com/que-es-razon-publica/.

Reed, M. (2012, enero 16). Bandas criminales: la genética no miente. Razón Pública. https://razonpublica.com/bandas-criminales-la-genetica-nomiente/.

Restrepo, D. A. (2017, julio 24). Las zonas post-farc: territorios en disputa. Razón Pública. https://razonpublica.com/las-zonas-post-farc-territoriosen-disputa/.

Restrepo, D. A. (2018, enero 22). Tumaco, un posconflicto armado. Razón Pública. https://razonpublica.com/tumaco-un-posconflicto-armado/.

Restrepo, J. (2010, agosto 1). El des-escalamiento del conflicto y el aumento de los cultivos de coca. Razón Pública. https://razonpublica.com/el-desescalamiento-del-conflicto-y-el-aumento-de-los-cultivos-de-coca/.

Restrepo, J. (2011, marzo 7). Paramilitarismo: la amenaza sigue viva. Razón Pública. https://razonpublica.com/paramilitarismo-la-amenaza-sigueviva/.

Restrepo, J. A. y Nieto, C. (2016, octubre 24). Nuevo protocolo del cese del fuego: beneficios y peligros. Razón Pública. https://razonpublica.com/ nuevo-protocolo-del-cese-del-fuego-beneficios-y-peligros/.

Ruiz Segarra, A. (2018). A Data-Driven Analysis of Video Game Culture and the Role of Let's Plays in YouTube. (5934). [Master's Thesis, University of Western Ontario]. https://ir.lib.uwo.ca/etd/5934/.

Salazar, B. (2015, agosto 24). Las 1500 bandas delincuenciales. Razón Pública. https://razonpublica.com/las-1500-bandas-delincuenciales/.

Salazar, B. (2017, febrero 20). La violencia después de las FARC. Razón Pública. https://razonpublica.com/la-violencia-despues-de-las-farc/.

Sánchez, E. (2013, agosto 5). De violencia en violencia: dimensiones difusas del conflicto armado. Razón Pública. https://razonpublica.com/ de-violencia-en-violencia-dimensiones-difusas-del-conflicto-armado/.

Segura, R. \& Mechoulan, D. (2017, February 27). Made in Havana: How Colombia and the FARC Decided to End the War. SSRN. http:/ dx.doi.org/10.2139/ssrn.2969332. 
Serrano, Y. (2012). La desmovilización de dos grupos armados ilegales: análisis del cubrimiento por la prensa nacional. Suma Psicológica, 19(2), 63-74. https://bit.ly/31PEpRh.

Suárez J. L. \& Lizama-Mué Y. (2020). Victims of Language: Language as a Pre-condition of Transitional Justice in Colombia's Peace Agreement. In S. El-Masri, T. Lambert, \& J. Quinn (Eds.), Transitional Justice in Comparative Perspective. Memory Politics and Transitional Justice (pp. 97-127). Palgrave Macmillan.

Suárez, J. L. \& Lizama-Mué, Y. (2021, March 9). Why language matters? Colombia's passing theory of peace. Peacebuilding, 1-16. DOI: 10.1080/21647259.2021.1895614.

United Nations Development Program (2003). Conflicto, callejón con salida. Informe de Desarrollo Humano para Colombia [Hernando Gómez Buendía, Director]. http://hdr.undp.org/sites/default/files/ colombia_2003_sp.pdf.

Uribe, S. (2016, marzo 14). ¿Un Estado comprador de la hoja de coca? Razón Pública. https://razonpublica.com/un-estado-comprador-de-la-hoja-decoca/.

Uribe, S. (2016a, abril 4). Los cultivos de coca, las FARC y el posconflicto. Razón Pública. https://razonpublica.com/los-cultivos-de-coca-las-farcy-el-posconflicto/.

Uribe, S. (2016b, julio 25). La coca sigue viva y lo seguirá en el posconflicto. Razón Pública. https://razonpublica.com/la-coca-sigue-viva-y-loseguira-en-el-posconflicto/.

Uribe, S. (2017, marzo 13). El problema de la coca empeora... y no lo quieren ver. Razón Pública. https://razonpublica.com/el-problema-de-la-cocaempeora-y-no-lo-quieren-ver/

Valencia, L. (2010, agosto 9). Balances 2009: El declive inevitable de la seguridad democrática. Razón Pública. https://razonpublica.com/deuribe-a-santos-el-estado-de-la-nacion/.

Vargas, A. (2015, febrero 8). Negociaciones en La Habana: ¿estamos en la recta final? Razón Pública. https://razonpublica.com/negociaciones-enla-habana-estamos-en-la-recta-final/. 
Villarraga, A. (2012, septiembre 17). El camino de la paz: Valorar las experiencias pasadas. Razón Pública. https://razonpublica.com/elcamino-de-la-paz-valorar-las-experiencias-pasadas/.

Villarraga, A. (2014, diciembre 22). El proceso de paz: balance y perspectiva 2014-2015. Razón Pública. https://razonpublica.com/el-proceso-de-pazbalance-y-perspectiva-2014-2015/.

Villarraga, A. (2015a, febrero 16). Cese unilateral y desescalamiento del conflicto: lo que viene en las negociaciones. Razón Pública. https:// razonpublica.com/cese-unilateral-y-desescalamiento-del-conflicto-loque-viene-en-las-negociaciones/.

Villarraga, A. (2015b, julio 13). Cese bilateral y definitivo: un camino hacia la paz. Razón Pública. https://razonpublica.com/cese-bilateral-ydefinitivo-un-camino-hacia-la-paz/.

Villarraga, A. (2016, febrero 8). Negociaciones de paz: en la recta final. Razón Pública. https://razonpublica.com/negociaciones-de-paz-en-larecta-final/.

Villarraga, A. (2017, septiembre 11). La historia de las disidencias guerrilleras: una advertencia para la construcción de paz. Razón Pública. https://razonpublica.com/la-historia-de-las-disidenciasguerrilleras-una-advertencia-para-la-construccion-de-paz/.

Voelkel, C. (2014a, marzo 30). Es el tiempo para el ELN. Razón Pública. https://razonpublica.com/es-el-tiempo-para-el-eln/.

Voelkel, C. (2014b, junio 16). El anuncio sobre las conversaciones con el ELN: sus avances, vacíos y efectos. Razón Pública. https://razonpublica. com/el-anuncio-sobre-las-conversaciones-con-el-eln-sus-avancesvacios-y-efectos/.

Voelkel, C. (2015a, enero 18). Anuncios de paz del ELN: ¿mucho ruido, pocas nueces? Razón Pública. https://razonpublica.com/anuncios-depaz-del-eln-mucho-ruido-pocas-nueces/.

Voelkel, C. (2015b, abril 27). ¿Tiene futuro el proceso de paz con el ELN? Razón Pública. https://razonpublica.com/tiene-futuro-el-proceso-depaz-con-el-eln/. 
Voelkel, C. (2015c, julio 20). Verificación del fin del conflicto armado: los retos y las opciones. Razón Pública. https://razonpublica.com/ verificacion-del-fin-del-conflicto-armado-los-retos-y-las-opciones/.

Voelkel, C. (2021). In LinkedIn (Profile): https://www.linkedin.com/in/ christian-voelkel-84b3bb5/detail/recent-activity/.

Wills, M. E. (2015). Los tres nudos de la guerra en Colombia. En Comisión Histórica del Conflicto y sus Víctimas, Contribución al entendimiento del conflicto armado en Colombia (pp. 813-860). Desde Abajo.

Ylä-Anttila, T., Eranti, V., \& Kukkonen, A. (2018, March 20). Topic Modeling as a Method for Frame Analysis: Data Mining the Climate Change Debate in India and the USA. https://doi.org/10.31235/osf.io/ $\operatorname{dgc} 38$.

Zuleta, H. (2017, octubre 30). Coca, violencia y sustitución de cultivos. Razón Pública. https://razonpublica.com/coca-violencia-y-sustitucionde-cultivos/.

Zuluaga Nieto, J. (2013, octubre 9). Diálogos de paz con el ELN: alcances y perspectivas. Razón Pública. https://razonpublica.com/dialogos-de-pazcon-el-eln-alcances-y-perspectivas/.

Zuluaga, J. (2018, enero 15). ELN: ¡cómo superar la incertidumbre y llegar a un acuerdo? Razón Pública. https://razonpublica.com/eln-comosuperar-la-incertidumbre-y-llegar-a-un-acuerdo/. 